\title{
EVALUASI LANSKAP SITU-FRONT SEBAGAI PENGEMBANGAN WATERFRONT DI KAWASAN CIBINONG RAYA, KABUPATEN BOGOR
}

\author{
Evaluation of the Situ-front Landscape \\ as Waterfront Development \\ in Cibinong Raya, Bogor Regency
}

\section{Intan Dewi Puspita}

Mahasiswa Sekolah Pascasarjana IPB, Program Studi Arsitektur Lanskap

Email : intandepita@gmail.com

\section{Indung Sitti Fatimah}

Staf Pengajar Departemen Arsitektur Lanskap, Fakultas Pertanian IPB

\author{
Andi Gunawan \\ Staf Pengajar Departemen Arsitektur \\ Lanskap, Fakultas Pertanian IPB
}

\begin{abstract}
Infrastructure development is a process of utilization of natural resources and human resources as well as science and technology in it. Cibinong Raya which is the capital city of Kabupaten Bogor is conducting regional development by utilizing natural resources as the characteristics of its region that is by utilizing 17 small urban lakes in that region. The existence of small lakes in Cibinong Raya will be developed as waterfront area. Waterfront is a zone of interaction between water body and urban development. The waterfront development basically is to manage urban areas so the orientation is facing the waters with the aim to improve environment quality. However, the lakes in Cibinong Raya has different size and physical conditions distinct from one another that could affect the priorities in its development. This study was conducted to evaluate the landscape around lakes in Cibinong Raya in accordance with the concept of waterfront development. The method used in this study is checklist form which has been compiled from literature. The assessment for the lakes condition in Cibinong Raya applies some criteria that is (1) the waterfront criteria, (2) riparian ecosystem status criteria, and (3) criteria for the status of aquatic ecosystems. The results showed that there are three lakes that have a good landscape conditions and four lakes has passably conditions to waterfront developmet.
\end{abstract}

Keywords: Cibinong Raya, lake, landscape, waterfront development

\section{PENDAHULUAN}

\section{Latar Belakang}

Pembangunan kota terus dilakukan oleh pemerintah daerah untuk meningkatkan kualitas hidup dan menambah infrastruktur di kotanya. Pada dasarnya, pembangunan kota merupakan proses pemanfaatan sumber daya alam dan sumber daya manusia serta ilmu pengetahuan dan teknologi di dalamnya. Cibinong Raya merupakan Ibu Kota Kabupaten Bogor. Sebagai kota yang strategis di antara Kota Depok dan Kota Bogor, pembangunan Cibinong Raya sebagai pusat pertumbuhan primer mendukung pertumbuhan kawasan metropolitan di sekitarnya dapat dikembangkan sesuai dengan potensi yang dimilikinya. Saat ini, Cibinong Raya sedang membangun daerah dengan membentuk identitas dan memperkuat karakter kotanya.

Badan Perencana Pembangunan Daerah (Bappeda) Kabupaten Bogor merencanakan Cibinong Raya sebagai pusat kegiatan dan pemerintahan akan dikembangkan menjadi kota yang memiliki citra dan karakteristik kota tersendiri. Konsep yang digunakan oleh Bappeda Kabupaten Bogor dalam pengembangan Cibinong Raya adalah situ-front city yang merupakan pengembangan dari waterfront city. Dilihat dari morfologi kotanya, Cibinong Raya memiliki 17 situ (danau kecil dalam Bahasa Sunda) dalam SK Bupati Bogor No. 17 dari 93 situ yang ada di Kabupaten Bogor. Keberadaan situ-situ ini menjadi sumber daya alam dan sekaligus menjadi potensi untuk pembangunan di Cibinong Raya.

Waterfront merupakan zona interaksi diantara perairan dan kawasan pengembangan kota (Yassin dan McDonagh, 2011). Secara harfiah, waterfront dapat diartikan sebagai suatu area atau kawasan yang terletak di tepi air (Tangkuman dan Tondobala, 2011), termasuk kawasan tangkapan air antara daerah daratan dan perairan (pantai/sungai/danau/situ) yang merupakan wadah bagi aktivitas masyarakat sekitarnya. Pembangunan kawasan tepi air mampu memasukkan nilai manusia akan kebutuhan ruang publik dan nilai alam di dalamnya (Somba, 2014). Pengembangan waterfront pada dasarnya menata kawasan perkotaan yang terletak di tepi air dan mengubah orientasi ke arah perairan. Perubahan orientasi pada pembangunan kota ke arah perairan, dapat meningkatkan kualitas perairan itu sendiri.

Hasil rapat kerja (Raker) situ-front city di Cibinong Raya menunjukkan bahwa ke-17 situ memiliki kondisi berbeda dari kondisi baik hingga rusak berat. Kondisi rusak berat pada situ tersebut diakibatkan oleh pendangkalan akibat erosi tanah di sekitarnya, pembuatan keramba liar, dan pencemaran akibat limbah budidaya ikan, industri, dan rumah tangga. Penggunaan konsep Situ-front city di Cibinong Raya menjadi solusi atas penurunan kualitas lingkungan di sekitar situ dan menjadi nilai estetika kota. Pengembangan situ-front menjadi tugas yang menantang bagi pemerintah daerah. 
Keberadaan waterfront menjadikan kota sebagai tempat yang nyaman tidak hanya untuk wisatawan yang berkunjung, tetapi juga sebagai tempat tinggal warganya (Lagarense, 2013).

Tujuan umum penelitian ini adalah untuk mengevaluasi lanskap di sekitar situ di Cibinong Raya untuk dapat dikembangkan menjadi situ-front city. Secara khusus, tujuan dari penelitian ini adalah (1) menyusun lembar penilaian untuk menilai lanskap sekitar situ di Cibinong Raya, dan (2) menentukan prioritas pengembangan situfont city pada situ-situ tersebut berdasarkan skor penilaian. Batasan penelitian dikhususkan pada kondisi fisik dan visual dari lanskap di sekitar situ dan penilaian dilakukan pada komponen pengembangan waterfront, komponen status ekosistem sempadan, dan komponen status ekosistem akuatik.

Penelitian ini diharapkan dapat membantu pemerintah daerah khususnya Bappeda Kabupaten Bogor dalam menata situ-situ di Cibinong Raya. Prioritas dalam pengembangan situ-front dapat menggunakan hasil penilaian dengan skor tertinggi sebagai masukan pengembangannya. Variabel yang belum terpenuhi pada penilaian situ dapat menjadi acuan dalam memperbaiki kualitas sekitar situ untuk dapat dikembangkan menjadi situ-front city.

\section{METODE}

\section{Waktu dan Lokasi Penelitian}

Penelitian dilakukan di Cibinong Raya yang merupakan tempat ke-17 situ tersebar. Cibinong Raya terdiri dari enam kecamatan, yakni Kecamatan Cibinong, Kecamatan Tajurhalang, Kecamatan Bojong Gede, Kecamatan Sukaraja, Kecamatan Babakan Madang, dan Kecamatan Citeureup seperti pada Gambar 1. Waktu penelitain berlangsung selama tiga bulan dari bulan Februari-April 2016.

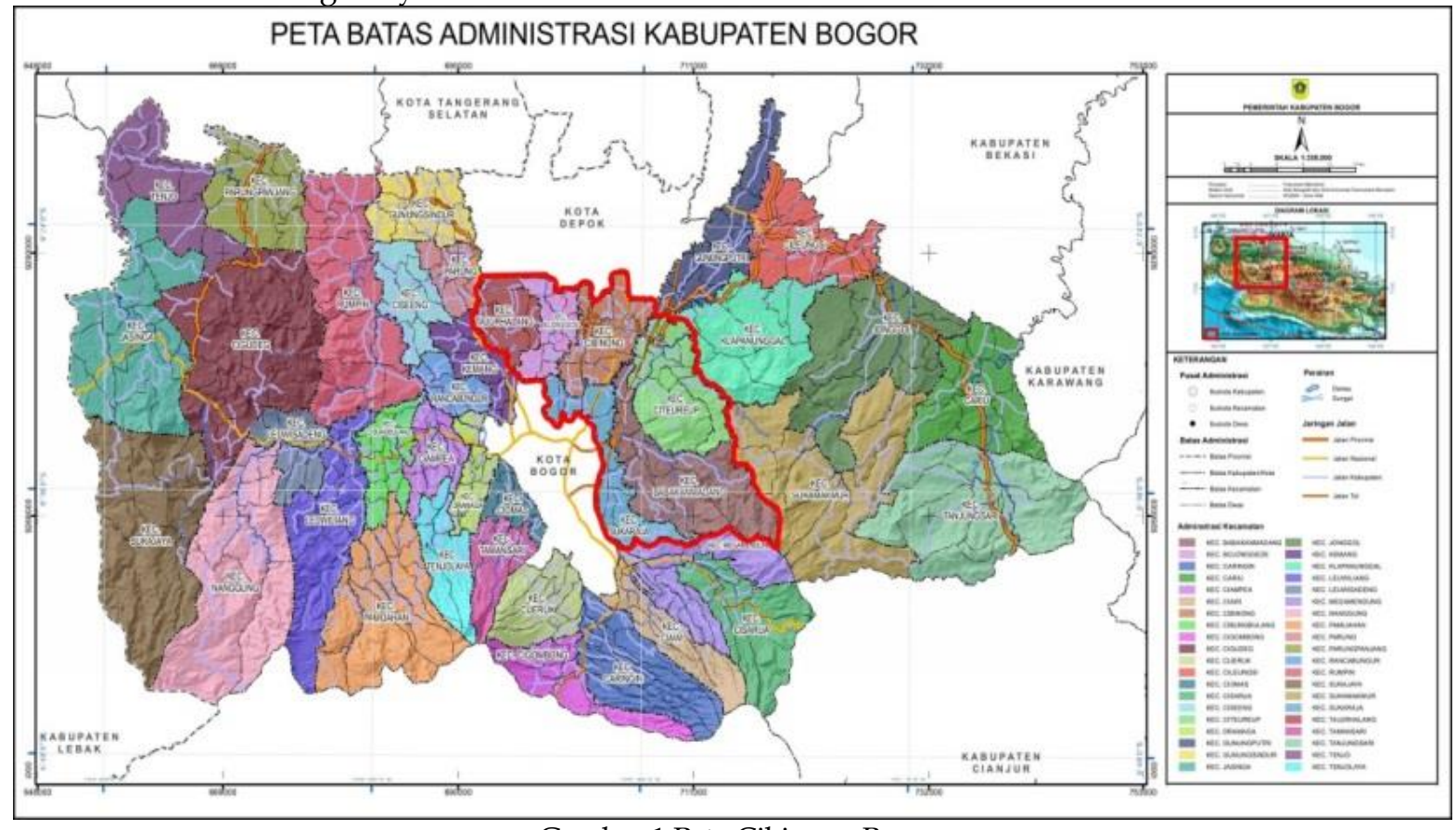

\section{Metode Penelitian}

Penelitian ini merupakan penelitian evaluatif yang digunakan untuk membandingkan kondisi nyata dengan kondisi yang diharapkan dengan menggunakan tolok ukur atau kriteria (Arikunto, 2010). Metode yang digunakan yakni observasi dengan menggunakan instrumen checklist. Terdapat tiga tahap dalam penelitian ini, (1) menyusun lembar checklist, (2) uji validitas, pembobotan, dan reliabilitas pada lembar checklist, dan (3) penilaian lanskap situ menggunakan lembar checklist.
1. Menyusun lembar checklist

Lembar checklist disusun berdasarkan studi pustaka digunakan untuk menelaah komponen dan variabel dalam penilaian lanskap situ. Komponen yang digunakan dalam penilaian adalah komponen pengembangan waterfront dari Prabudiantoro (1997, dalam Soesanti et al. 2006 dan Tangkuman dan Tondobala 2011), komponen ekosistem sempadan, dan komponen ekosistem akuatik (Irianto dan Triweko, 2011). Parameter pada kriteria lembar checklist dijelaskan dalam tiga kondisi sesuai dengan studi pustaka yang didapat yakni, baik (skor 3) merupakan kondisi dimana 
eksisting memenuhi kriteria untuk dikembangkan sebagai waterfront; cukup baik (skor 2) bermakna kondisi eksisting memenuhi kriteria, namun masih ada yang harus diperbaiki dari kondisi lingkungannya; dan kurang baik (skor 1) artinya kondisi eksisting belum bisa dikembangkan sebagai waterfront dan harus membenahi kondisi lingkungannya.

Komponen dan variabel yang sudah disusun pada lembar checklist, kemudian diuji validitas dan reliabilitasnya sebelum digunakan untuk menilai lanskap situ. Lembar checklist yang sudah diuji validitas dan reliabilitas, dapat digunakan untuk menilai lanskap situ di Cibinong Raya. Lanskap situ akan dinilai oleh enam orang penilai untuk menghindari subjektifitas dengan identitas penilai dapat dilihat di Tabel 1.

Tabel 1 Identitas penilai lanskap situ

\begin{tabular}{llc}
\hline $\begin{array}{l}\text { Bidang } \\
\text { Keahlian }\end{array}$ & \multicolumn{1}{c}{ Asal Institusi } & $\begin{array}{c}\text { Jum } \\
\text { lah }\end{array}$ \\
\hline $\begin{array}{l}\text { Teknik } \\
\text { Arsitektur }\end{array}$ & $\begin{array}{l}\text { Mahasiswa Pascasarjana, Departemen } \\
\text { Arsitektur Lanskap, FAPERTA IPB }\end{array}$ & 3 \\
\hline Agribisnis & $\begin{array}{l}\text { Mahasiswa Pascasarjana, Departemen } \\
\text { Arsitektur Lanskap, FAPERTA IPB }\end{array}$ & 1 \\
\hline Agroteknologi & $\begin{array}{l}\text { Mahasiswa Pascasarjana, Departemen } \\
\text { Arsitektur Lanskap, FAPERTA IPB }\end{array}$ & 1 \\
\hline Biologi & $\begin{array}{l}\text { Mahasiswa Pascasarjana, Departemen } \\
\text { Arsitektur Lanskap, FAPERTA IPB }\end{array}$ & 1 \\
\hline
\end{tabular}

2. Uji validitas, pembobotan, dan reliabilitas lembar checklist

Lembar checklist yang sudah disusun oleh peneliti, kemudian diuji validitas dan bobotnya menggunakan pendapat pakar/ahli (expert judgment) untuk setiap komponen dan variabel yang menentukan validitas isi dari instrumen ini. Validitas isi merupakan validitas yang diestimasi lewat pengujian terhadap kelayakan atau relevansi isi tes melalui analisis rasional oleh panel yang berkompeten atau melalui expert judgment. Para pakar secara cermat melihat keseluruhan materi yang ada sebagai alat ukur yang memang secara representatif terwakili oleh pernyataan yang dibuat. Selanjutnya meminta justifikasi pakar sebanyak 3 orang pakar, mengenai relevansi lembar chesklist penilaian lanskap situ untuk pengembangan waterfront berdasarkan komponen/aspek yang telah disusun. Penilaian oleh pakar dapat dijadikan alternatif bukti validitas, tergantung pada latar belakang pengetahuannya (Mardapi, 2008). Bobot setiap variabel yang diperoleh, akan menentukan peran setiap pernyataan pada lembar checklist dalam menilai lanskap situ untuk dikembangkan sebagai waterfront.

Masing-masing variabel dari setiap komponen akan dinilai oleh pakar, apakah setiap butir pernyataan dapat menilai tujuan yang diinginkan atau tidak. Pakar menilai setiap butir pernyataan dibagi atas tiga interval, yakni dapat digunakan, digunakan dengan modifikasi, dan tidak dapat digunakan. Sebagai tambahan, pakar dapat mengajukan pernyataan lain untuk menambah komponen dan variabel dari lembar checklist. Identitas pakar dalam menguji validitas dan pembobotan pada instrumen checklist dapat dilihat pada Tabel 2.

Uji reliabilitas instrumen pada lembar checklist tidak begitu ditekankan. Karena yang terpenting dalam penelitian adalah kebenaran data, data yang reliabel, dan data yang sesuai dengan keadaan yang sebenarnya (Arikunto, 2010). Namun dalam penelitian observasi jika terdapat lebih dari dua orang pengamat/penilai, harus diadakan penyamaan antar-pengamat sampai mendapatkan persamaan persepsi dari semua pengamat yang akan bekerja mengumpulkan data. Pengukuran reliabilitas antar penilai dengan tiga atau lebih penilai, dapat menggunakan intraclass correlation coefficients (ICC) atau koefisien korelasi intra kelas (McHugh, 2012), dengan rumus sebagai berikut

$$
\begin{array}{cl}
\text { Keterangan: } & \\
\text { ICC } & =\text { intraclass correlation coefficients } \\
\sigma^{2} & =\text { ukuran variasi } \\
\mathrm{S} & =\text { subjek (indicator penilaian) } \\
\mathrm{o} & =\text { objek(pengamat/ penilai) } \\
\mathrm{e} & =\text { random error }
\end{array}
$$

$$
\mathrm{ICC}=\frac{\sigma_{\mathrm{s}}^{2}}{\sigma_{\mathrm{s}}^{2}+\sigma_{\mathrm{o}}^{2}+\sigma_{\mathrm{e}}^{2}}
$$

Tabel 2 Rincian responden pakar

\begin{tabular}{llc}
\hline $\begin{array}{l}\text { Bidang } \\
\text { Keahlian }\end{array}$ & Asal Institusi/ lembaga & Jumlah \\
\hline $\begin{array}{l}\text { Arsitektur } \\
\text { Lanskap }\end{array}$ & $\begin{array}{l}\text { Departemen Arsitektur } \\
\text { Lanskap, FAPERTA IPB }\end{array}$ & 2 \\
\hline $\begin{array}{l}\text { Sumber daya } \\
\text { Air }\end{array}$ & $\begin{array}{l}\text { Departemen Teknik Sipil dan } \\
\text { Lingkungan, FATETA IPB }\end{array}$ & 1 \\
\hline
\end{tabular}

\section{Penilaian lanskap situ}

Tahap selanjutnya yakni menilai lanskap situ yang ada di Cibinong Raya. Ukuran badan air perlu dipertimbangkan dari segi luasannya, karena apabila terlalu kecil kurang optimal untuk dikembangkan sebagai kawasan waterfront perkotaan. Di dalam penelitian ini, ukuran badan air situ yang ada di Cibinong Raya akan dibatasi luasannya. Menurut New York State Departement of Environmental Conservation (2009), disebutkan bahwa ambang batas untuk danau/waduk lebih besar dari 6.4 acre $( \pm 2.5 \mathrm{Ha})$ untuk dapat dimasukkan dalam persediaan badan air. Ukuran batasan danau ini yang akan digunakan dalam penelitian sebagai luas minimal situ yang selanjutnya akan dinilai juga untuk mengefektifkan penilaian pada situ-situ di Cibinong Raya. 
Setelah didapat situ yang memiliki luas badan air $\geq 2.5$ $\mathrm{Ha}$, selanjutnya penilaian lanskap situ akan dilakukan dengan pengamatan di lapangan berpedoman pada lembar checklist. Penilaian situ di Cibinong Raya dilakukan oleh 6 orang untuk menghindari subjektivitas penilaian pada setiap penilaian lanskap situ. Hasil penilaian lanskap situ merupakan rata-rata dari skor total 6 orang penilai yang kemudian dikategorikan ke dalam tiga kelas interval. Jarak antara kelas interval dicari dengan menggunakan kaidah Sturgess dalam Sugiarto (2006), yakni mencari selisih jumlah skor terbesar dikurangi dengan jumlah skor terkecil dibagi dengan banyaknya kelas interval. Kategori dan kelas interval penilaian lanskap situ dari masing-masing variabel dikelompokkan menjadi 3 kelas interval yakni,

- $\quad$ kondisi lanskap baik, apabila rata-rata skor total antara 2.33-3.00,

- $\quad$ kondisi lanskap cukup baik, apabila rata-rata skor total antara 1.67-2.32,

- dan kondisi lanskap kurang baik, apabila rata-rata skor total antara 1.00-1.66.

\section{HASIL DAN PEMBAHASAN}

\section{Kondisi Umum Lokasi Penelitian}

1. Aspek biofisik

Kabupaten Bogor secara geografis terletak antara $6^{\circ} 18^{\prime}-$ $6^{\circ} 47^{\prime}$ LS dan $106^{\circ} 23^{\prime} 45-107^{\circ} 13^{\prime} 30$ BT. Cibinong Raya merupakan wilayah administrasi Pemerintah Kabupaten Bogor dengan luas wilayah Cibinong Raya sebesar 31.107 Ha. Batas-batas wilayah Cibinong Raya yakni, sebelah Utara berbatasan dengan Kota Depok; sebelah Timur berbatasan dengan Kecamatan Gunung Putri, Kecamatan Kelapa Nunggal, Kecamatan Sukamakmur; sebelah Selatan berbatasan dengan Kecamatan Megamendung; dan di Barat berbatasan dengan Kota Bogor, Kecamatan Parung, dan Kemang.

Tipe morfologi wilayah Cibinong Raya bervariasi, dari dataran rendah di bagian utara hingga dataran tinggi di bagian selatan. Sekitar 84\% wilayah Cibinong Raya berada pada ketiggian < $500 \mathrm{mdpl}, 10.9 \%$ berada pada ketinggian 500-700 mdpl, dan sekitar $4.7 \%$ berada pada ketinggian $>700 \mathrm{mdpl}$. Secara umum, kondisi iklim di Kabupaten Bogor tahun 2014 rata-rata berkisar antara $22.7^{\circ} \mathrm{C}$ sampai $31.6^{\circ} \mathrm{C}$. Suhu udara maksimum terjadi pada bulan September yakni $36.0^{\circ} \mathrm{C}$. Sedangkan suhu udara minimum terjadi di bulan September juga mencapai $19.2{ }^{\circ} \mathrm{C}$ (Badan Pusat Statistik Kabupaten Bogor, 2015).

2. Aspek sosial ekonomi

Faktor kependudukan memiliki peran yang penting dalam pembangunan kota. Jumlah penduduk yang semakin meningkat membuat pemerintah daerah melakukan pembangunan untuk memenuhi fasilitas dan infrastruktur kota tersebut. Jumlah penduduk Cibinong Raya sebanyak 1.315.858 jiwa pada tahun 2014 dan akan terus meningkat (Badan Pusat Statistik Kabupaten Bogor, 2015). Rata-rata kepadatan penduduk di Cibinong Raya sebanyak 43 jiwa/Ha. Sarana dan prasarana di Cibinong Raya cukup memadai dengan adanya komplek pemerintahan yang berpusat di Kecamatan Cibinong.

Perkembangan Cibinong Raya sebagai Ibu Kota Kabupaten Bogor sangat cepat. Pembangunan insfrastruktur perkotaan banyak dilakukan untuk mengimbangi pertumbuhan penduduknya. Arahan pengembangan di wilayah Cibinong Raya meliputi pada Pengembangan kegiatan sebagai pusat pemerintahan, perdagangan dan jasa, pusat pelayanan sosial, pusat komunikasi, pusat permukiman perkotaan, pariwisata dan budaya, industri ramah lingkungan (Bupati Bogor, 2008).

\section{Aspek wisata}

Situ-situ di Cibinong Raya memiliki banyak potensi sumber daya alam dan budaya di dalamnya. Pada tahun 2013, oleh Disbudpar Kabupaten Bogor dikembangkan objek wisata tirta di tiga situ, yakni situ Cikaret, situ Kebantenan, dan situ Pemda. Keberadaan situ-situ lain juga memberikan ruang rekreasi bagi masyarakat di sekitarnya baik untuk relaksasi ataupun kegiatan memancing.

Tidak hanya tujuan wisata, Situ Cikaret sebagai situ yang memiliki luas paling besar dari pada situ yang lainnya, juga sering digunakan untuk kegiatan-kegiatan budaya seperti lomba dayung perahu tradisional yang diselenggarakan untuk memperingati hari jadi Bogor ke528. Peringatan HUT RI ke-71 juga, Badan Penanggulangan Bencana Daerah (BPBD) Kabupaten Bogor menyelenggarakan lomba dayung perahu karet untuk menyiapkan anggota tim pemadam kebakaran.

\section{Aspek hidrologi}

Hidrologis wilayah Cibinong Raya terbagi ke dalam tiga Daerah Aliran Sungai (DAS), yakni DAS Ciliwung, DAS Angke, dan DAS Bekasi. Situ-situ di Cibinong Raya mendapat pasokan air dari sungai-sungai besar seperti Sungai Ciliwung, Cikeas, Cileungsi, dan Kali Bekasi. Situ yang terletak di DAS Ciliwung seperti Situ Cikaret, Situ Kebantenan, Situ Pemda, Situ Cibeureum, Situ Cijantung, dan Situ Sela merupakan bagian dari DAS Ciliwung tengah. Sedangkan situ-situ yang terdapat di DAS Angke (Situ Tonjong, Situ Kemuing, Situ Cimanggis, Situ Nanggerang, dan Situ Kandang Babi) dan Sub-DAS Cikeas seperti Situ Cibinong, Situ Citatah, 
Situ Cibuntu, Situ Cijujung, Situ Cipambuan Hilir, sedangkan Situ Leuwinutug merupakan bagian dari DAS Kali Bekasi bagian hulu.

Ke-17 situ tersebut tersebar di enam kecamatan di Cibinong Raya seperti pada Gambar 2. Kondisi dari 17 situ tersebut tidak semua dalam keadaan yang baik.
Data ke-17 situ tersebut dapat dilihat pada Tabel 3. Tabel 3 menunjukkan bahwa situ yang memiliki badan air $\geq$ 2,5 Ha sebanyak 7 situ. Ketujuh situ ini yang akan dinilai kondisi lanskapnya menggunakan lembar checklist.

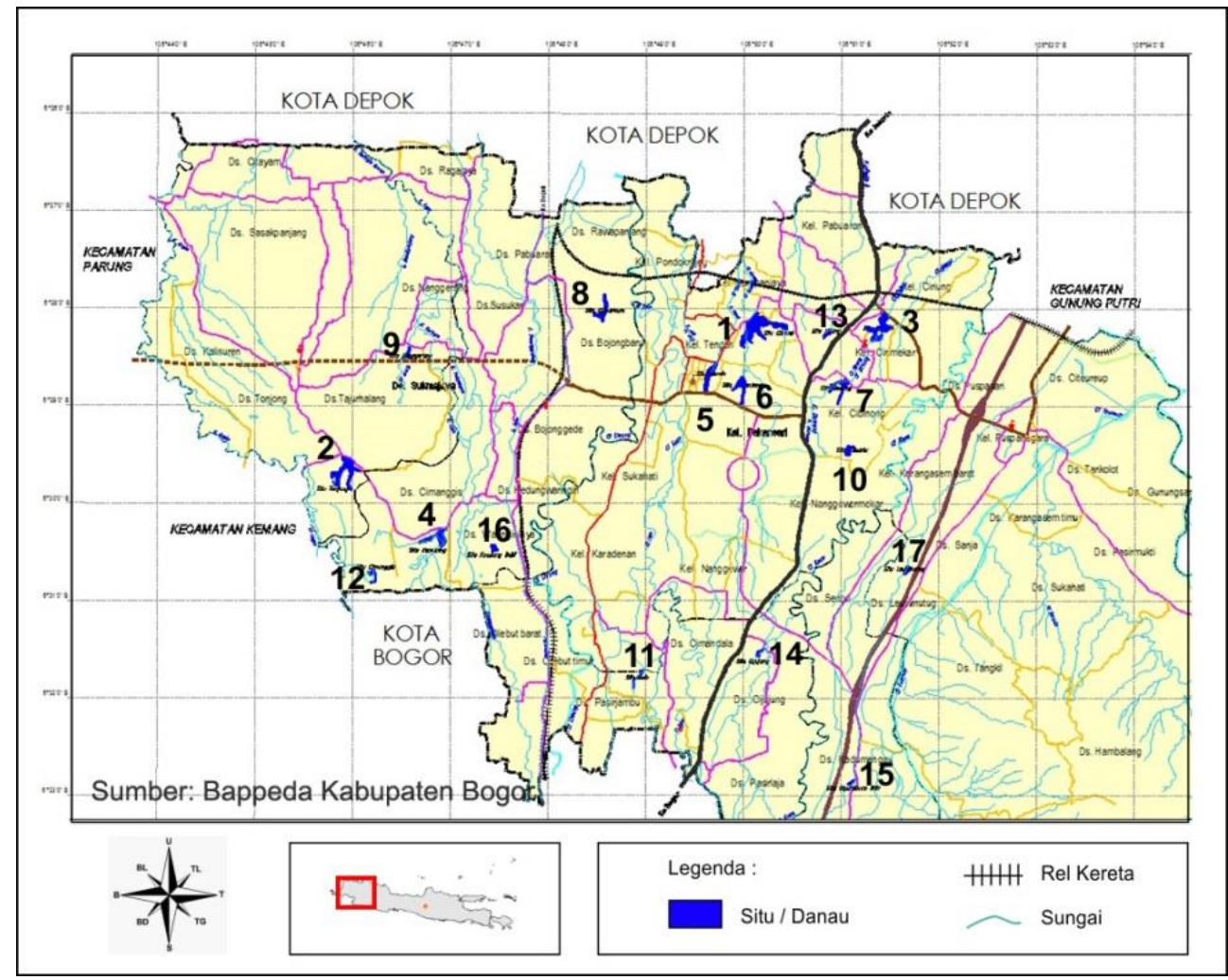

Gambar 2 Lokasi 17 situ di Cibinong Raya

Tabel 3 Data inventarisasi situ di Cibinong Raya

\begin{tabular}{clcccc}
\hline No & \multicolumn{1}{c}{ Nama Situ } & Kecamatan & $\begin{array}{c}\text { Luas SK } \\
\text { (Ha) }\end{array}$ & $\begin{array}{c}\text { Luas } \\
\text { Eksisting* } \\
\text { (Ha) }\end{array}$ & $\begin{array}{c}\text { Kondisi } \\
\text { Eksisting }\end{array}$ \\
& & & 29.5 & 18 & Baik \\
Baik & Rusak Ringan \\
2 & Cikaret & Cibinong & 14.44 & 11.6 & Baik \\
3 & Citatah/Ciriung & Tajurhalang & 9.25 & 10.5 & Baik \\
4 & Kemuning & Cibinong & 21 & 6.5 & Baik \\
5 & Baru/Pemda & Bojong Gede & 6.2 & Sedang \\
6 & Kabantenan & Cibinong & 4.5 & 4.5 & Rusak Ringan \\
7 & Cibeureum & Cibinong & 2.5 & 2.5 & Baik \\
8 & Cibinong/Gedong & Bojong Gede & 4 & 2.3 & Sedang \\
9 & Cibuntu & Cibinong & 6 & 2.12 & Baik \\
10 & Cimanggis & Cibinong & 2 & 1.65 & Rusak Berat \\
11 & Cijantung/Kibing & Cibinong & 2 & 0.8 & Baik \\
12 & Kandang Babi & Bojong Gede & 1.5 & 0.7 & Rusak Berat \\
13 & Sela & Cibinong & 1.5 & 0.5 & Rusak Ringan \\
14 & Cijujung & Sukaraja & 1 & 0.1 & Rusak Berat \\
15 & Cipambuan Hilir & Babakan Madang & 0.75 & 0.2 & Rusak Berat \\
16 & Leuwi Nutug & Citereup & 1.28 & 2 & 0 \\
17 & Nanggerang & Tajurhalang & 2 & & \\
\hline
\end{tabular}

Sumber: Forum Group Discussion ke-3 2015 oleh Bappeda 
Komponen dan variabel lembar checklis didapat dari studi pustaka yang kemudian disusun menjadi kriteria yang dapat dinilai. Studi pustaka yang sudah dilakukan menghasilkan 11 variabel dari tiga komponen, yakni kedekatan dengan badan air, akses, fungsi kawasan, orientasi bangunan, tinggi bangunan, bangunan di sekitar sempadan, vegetasi riparian, kualitas perairan, tumbuhan air, bau dan warna, dan penyusutan badan air. Kriteria yang digunakan pada setiap variabel, kemudian dibagi dalam tiga skala yang merupakan representasi dari kondisi maksimun (3), kondisi rata-rata (2), dan kondisi minimum (1) dari lokasi penelitian. Nilai yang dihasilkan merupakan rata-rata skor total dari 6 orang penilai. Penyusunan komponen dan variabel lembar checklist dapat dilihat pada Tabel 4.

\section{Hasil uji validitas, pembobotan, dan reabilitas lembar checklist}

Hasil uji validitas oleh ketiga pakar dan bobot masingmasing lembar checklist dapat dilihat pada Tabel 5. Tabel 5 menunjukkan komponen dan variabel yang digunakan dalam menilai lanskap di sekitar situ. Masing-masing variabel memiliki kriteria yang diperoleh dari pustaka

\section{Hasil penyusunan lembar checklist}

dan peraturan pemerintah sebagai dasar dalam menentukan skor maksimum dan skor minimum untuk lembar checklist. Lembar checklist yang sudah disusun kembali kemudian digunakan sebagai pedoman dalam penilaian lanskap situ di Cibinong Raya.

Lembar checklist yang sudah tersusun dapat langsung digunakan untuk menilai lanskap situ di Cibinong Raya. Lanskap situ dinilai oleh 6 orang penilai untuk menghindari subjektifitas dalam menilai lanskap situ. Hasil penilaian lanskap situ oleh 6 orang penilai, kemudian diuji reliabilitas antar penilai menggunakan koefisein korelasi intra kelas yang diolah menggunakan software SPSS. Analisis SPSS menunjukkan rata-rata kesepakatan penilai adalah 0.873. Koefisien korelasi tersebut menunjukkan bahwa kesepakatan penilai sangat tinggi (Hallgren, 2012). Perhitungan reliabilitas statistik antar 6 orang penilai adalah 0.976 yang artinya, reliabilitas antar penilai dalam instrumen ini sangat tinggi. Instrumen dikatakan reliabel apabila memiliki nilai koefisien reliabilitas (nilai akurasi instrumen dalam mengukur apa yang akan diukur) minimal 0.6 (Sugiyono, 2011).

Tabel 4 Komponen dan variabel penilaian waterfront

\begin{tabular}{|c|c|c|}
\hline Komponen/Variabel & Keterangan & Sumber \\
\hline \multicolumn{3}{|l|}{ Pengembangan Waterfront } \\
\hline 1. Kedekatan dengan sumber air & $\begin{array}{l}\text { Dalam dimensi kota, dikatakan dekat adalah } \\
\text { dengan jarak } 150 \mathrm{~m}\end{array}$ & $\begin{array}{l}\text { The Council of the Town (2015) dan New } \\
\text { York State Department of Conservation } \\
\text { (2009) }\end{array}$ \\
\hline 2. Akses ke sumber air & Modifikasi untuk kendaraan roda empat & $\begin{array}{l}\text { Sites Assessment Matrix } \\
\text { [www.theatfield.ny.us/DocumentCenter/ } \\
\text { View/46] }\end{array}$ \\
\hline 3. Fungsi kawasan & $\begin{array}{l}\text { Penggunaan campuran (mixed-use), minimal } \\
\text { memiliki } 3 \text { fungsi kawasan }\end{array}$ & Grant (2004) \\
\hline 4. Orientasi bangunan & $\begin{array}{l}\text { Orientasi pada bangunan sekitar mengarah } \\
\text { pada badan air }\end{array}$ & $\begin{array}{l}\text { Ditjen Cipta Karya } 2000 \text { dan Soesanti et al. } \\
\text { (2006) }\end{array}$ \\
\hline 5. Tinggi bagunan & 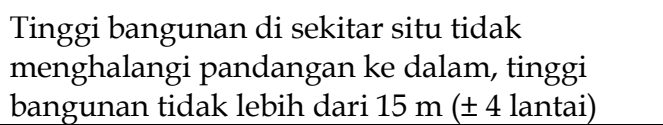 & Ditjen Cipta Karya 2000 \\
\hline \multicolumn{3}{|c|}{ Status Ekosistem Sempadan (dari muka air tertinggi - $100 \mathrm{~m}$ ) } \\
\hline 6. Bangunan disekitar sempadan & $\begin{array}{l}\text { Kepadatan maksismum bangunan tepi air } \\
\text { adalah } 25 \%\end{array}$ & $\begin{array}{l}\text { Permen PU No. 28/PRT/M/2015 dan } \\
\text { Ditjen Cipta Karya } 2000\end{array}$ \\
\hline 7. Vegetasi penyangga riparian & $\begin{array}{l}\text { Kombinasi antara rumput, semak, dan pohon } \\
\text { Riparian sebagai habitat satwa minimal sejauh } \\
50 \mathrm{~m}\end{array}$ & Truesdale (2008) \\
\hline \multicolumn{3}{|l|}{ Status Ekosistem Akuatik } \\
\hline $\begin{array}{l}\text { 8. Kualitas perairan (pencemaran } \\
\text { dari sampah permukiman dan } \\
\text { industri) }\end{array}$ & $\begin{array}{l}\text { Tidak tercemar oleh sampah ataupun minyak } \\
\text { dari hasil industri }\end{array}$ & $\begin{array}{l}\text { Irianto dan Triweko (2011) dan Rancangan } \\
\text { Peraturan Menteri Negara Lingkungan } \\
\text { Hidup } 2009\end{array}$ \\
\hline 9. Tutupan tumbuhan air & Terkendali, tidak tercemar, dan tidak & Irianto dan Triweko (2011) dan Kementrian \\
\hline
\end{tabular}




\begin{tabular}{|c|c|c|c|}
\hline & Komponen/Variabel & Keterangan & Sumber \\
\hline & & mengganggu fungsi danau & Negara Lingkungan Hidup 2008 \\
\hline 10. & Bau dan warna & Tidak menimbulkan bau dan warna & Dirjen PPM dan PLP Departemen \\
\hline 11. & Penyusutan badan air & Berdasarkan kondisi citra satelit & $\begin{array}{l}\text { Kesehatan (1977) } \\
\text { Hasil pengolahan data dari Bappeda } \\
\text { Cibinong pada FGD-3 Pemda Kab. Bogor }\end{array}$ \\
\hline
\end{tabular}

Tabel 5 Kriteria lembar checklist

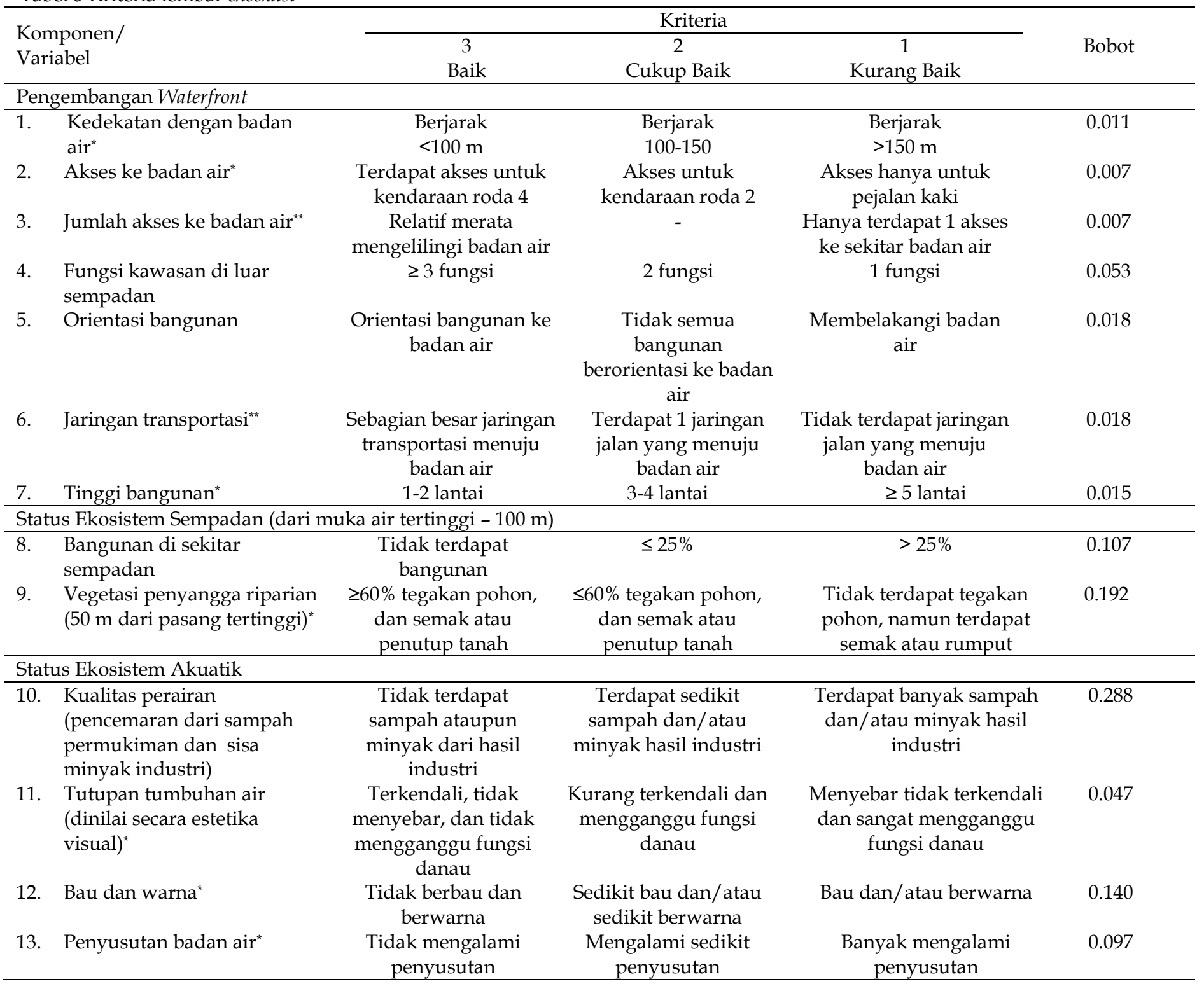

Keterangan: * layak dengan modifikasi; ${ }^{* *}$ masukan pakar

\section{Hasil penilaian lanskap situ}

Situ yang memiliki badan air $\geq 2.5$ Ha terdapat 7 situ yang akan dinilai lanskapnya. Situ-situ tersebut adalah Situ Cikaret, Situ Tonjong, Situ Citatah/Ciriung, Situ Kemuning, Situ Baru/Pemda, Situ Kebantenan, dan Situ Cibeureum. Ketujuh situ ini yang kemudian akan dinilai menggunakan lembar checklist yang sudah disusun untuk dapat dinilai kondisinya. Hasil rata-rata penilaian oleh 6 orang penilai terhadap 7 situ di Cibinong Raya dapat dilihat pada Tabel 6. Tabel 6 menunjukkan hasil penilaian situ-situ di Cibinong Raya yang merupakan rata-rata skor total dari 6 orang penilai pada setiap variabel. Skor total yang dikalikan dengan bobot dari keseluruhan variabel yang kemudian akan 
diinterpretasikan dalam kelompok interval yang merupakan kondisi dari lanskap situ yang sudah dibuat. Hasil penilaian ke-7 situ oleh 6 orang penilai menunjukkan bahwa terdapat 3 situ dalam kondisi baik (Gambar 3) dan 4 situ dalam kondisi cukup baik (Gambar 4). Situ Cibeureum (2.6) merupakan situ yang memiliki skor tertinggi dan dalam kondisi baik untuk pengembangan waterfront. Skor tertinggi berikutnya adalah Situ Baru/Pemda (2.56) dan Situ Cikaret (2.34) yang memiliki kondisi lanskap yang baik. Tersisa 4 situ dalam kondisi lanskap cukup baik untuk pengembangan waterfront di Cibinong Raya, yakni Situ Kebantenan (2.28), Situ Tonjong (2.25), Situ Kemuning (2.21), dan Situ Citatah/Ciriung (1.90).

Penilaian terhadap situ-situ tersebut, sangat dipengaruhi oleh kualitas perairan dan vegetasi penyangga riparian yang memiliki bobot paling tinggi diantara variabel yang lainnya. Pakar yang memberikan bobot pada lembar checklist meyakini bahwa kualita perairan dan vegetasi penyangga riparian memiliki keterkaitan satu dengan lainnya. Hal ini ditegaskan oleh U.S. Department of Agriculture (2003) dalam sebuah buku, bahwa konservasi daerah riparian dapat melindungi kualitas air dan menjaga habitat satwa di dalamnya.

Tutupan pohon pada Situ Cibeureum pada jarak $50 \mathrm{~m}$ dari titik air tertinggi sebanyak $60.39 \%$ berdasarkan hasil pengolahan data penelitian. Situ Cibeureum memiliki tutupan pohon yang lebih banyak dari pada Situ Citatah yang hanya memiliki tutupan pohon sebanyak $32.35 \%$ (Tabel 6). Situ Citatah terletak dekat dengan Pasar Cibinong, sehingga banyak aktivitas masyarak yang menghasilkan limbah sampah di sekitar Situ Citatah. Akibatnya, banyaknya sampah yang menumpuk di perairan situ Citatah. Sedangkan Situ Cibeureum terletak dekat dengan perumahan, yang pada dasarnya sedikit aktivitas/kegiatan masyarakatnya untuk mebuang sampah.

Situ Cibeureum memiliki kondisi yang lebih baik dari pada situ yang lainnya berdasarkan penilaian situ yang dipengaruhi oleh bobot masing-masing variabel. Namun secara penilaian lapangan oleh 6 orang penilai, Situ Pemda/Baru memiliki skor tertinggi dari pada situ yang lainnya berdasarkan variabel yang terpenuhi. Setiap situ memiliki kelebihan dan kekurangan pada lanskap sekitar situ yang perlihatkan pada Tabel 6 dalam bentuk skor sebagai kondisi eksisting dari kondisi lanskap dan perairan situ. Tindakan mitigasi yang dapat dilakukan berpedoman pada Tabel 6 untuk setiap situ dalam mengurangi dan meminimalkan dampak dari kondisi sekarang adalah sebagai berikut disajikan pada Tabel 7 . Tindakan penanganan untuk memperbaiki lanskap situ dalam pengembangan waterfront yang ada di Cibinong Raya, dapat memenuhi variabel yang kurang maksimal pada penilaian lanskap situ.

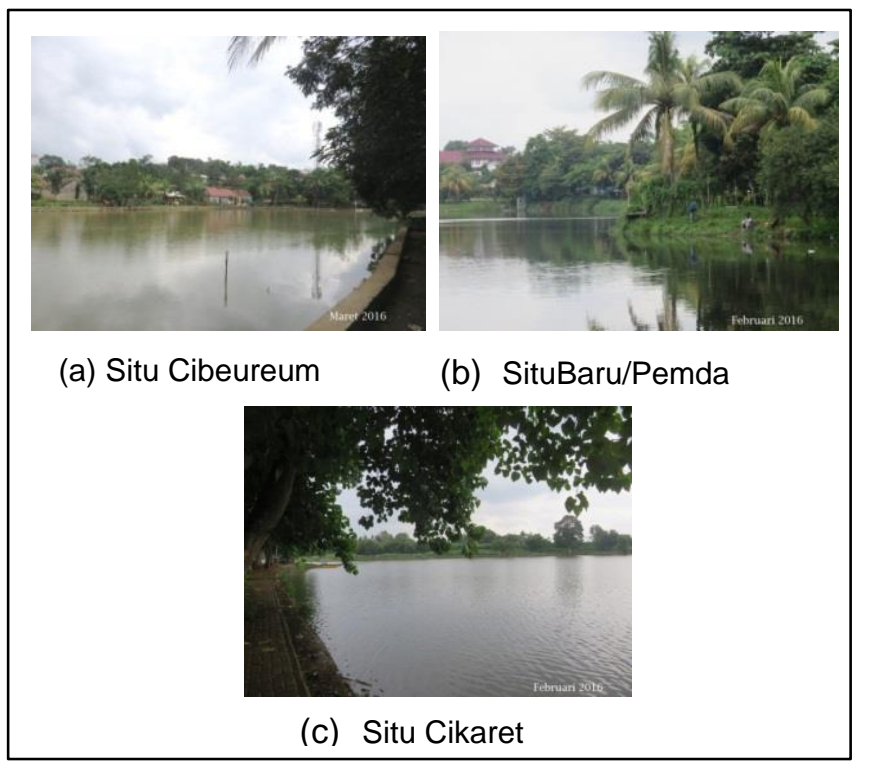

Gambar 3 Situ di Cibinong Raya dalam kondisi baik untuk dikembangkan sebagai waterfront

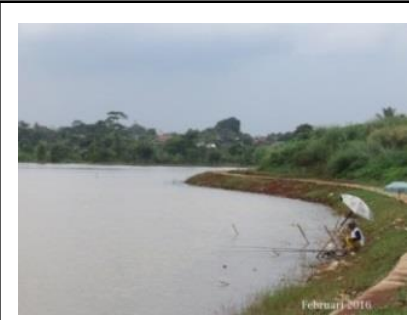

(a) Situ Kebantenan

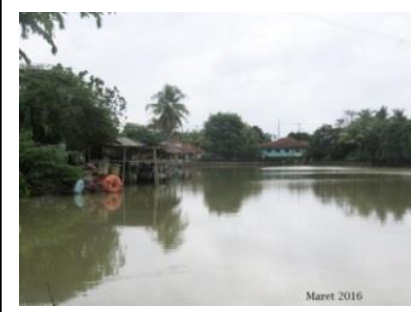

(c) Situ Kemuning

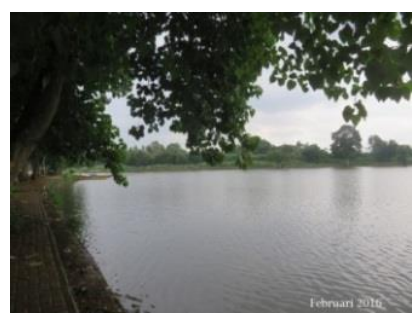

(b) Situ Tonjong

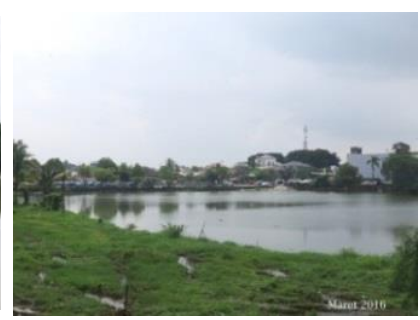

(d) Situ Citatah
Gambar 4 Situ di Cibinong Raya dalam kondisi cukup baik untuk dikembangkan sebagai waterfront 
Tabel 6 Hasil penilaian lanskap situ untuk pengembangan waterfront

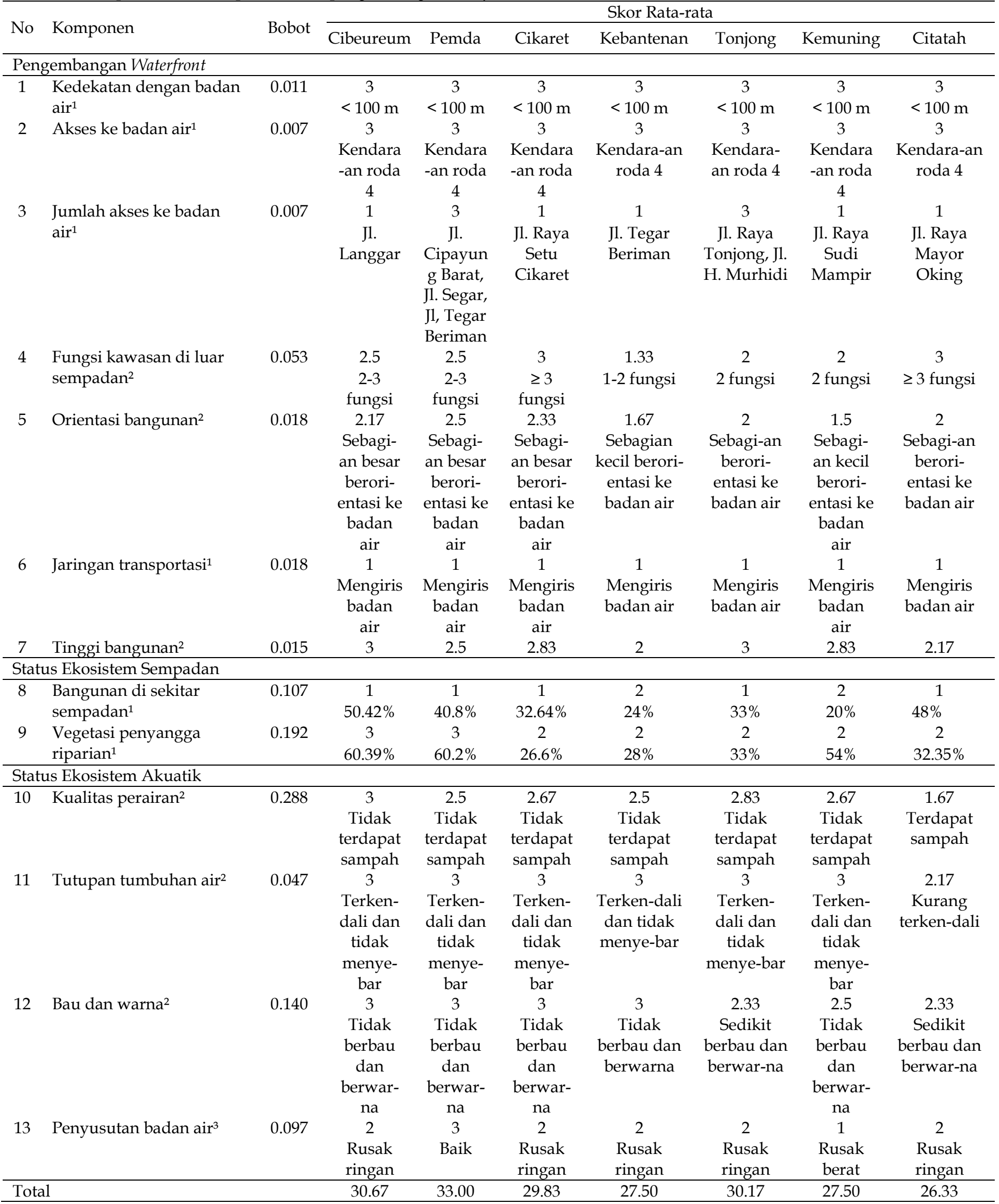




\begin{tabular}{lccccccccc}
\hline \multirow{2}{*}{ No Komponen } & \multirow{2}{*}{ Bobot } & \multicolumn{5}{c}{ Skor Rata-rata } \\
\cline { 3 - 8 } & & Cibeureum & Pemda & Cikaret & Kebantenan & Tonjong & Kemuning & Citatah \\
\hline Total $x$ Bobot & 2.60 & 2.56 & 2.34 & 2.28 & 2.25 & 2.21 \\
\hline Keterangan & B & B & B & CB & CB & CB & CB \\
\hline
\end{tabular}

Keterangan: $\mathrm{B}=$ Baik; $\mathrm{CB}=$ Cukup Baik

Sumber data: ${ }^{1}$ hasil pengolahan data; ${ }^{2}$ hasil penilaian lokasi; ${ }^{3}$ data Bappeda

Tabel 7 Tindakan mitigasi pada butir pernyataan yang tidak terpenuhi

\begin{tabular}{|c|c|c|c|c|c|c|c|c|c|}
\hline \multirow{2}{*}{ No } & \multirow{2}{*}{ Komponen } & \multicolumn{7}{|c|}{ Situ } & \multirow{2}{*}{ Tindakan Mitigasi } \\
\hline & & 1 & 2 & 3 & 4 & 5 & 6 & 7 & \\
\hline 1 & Kedekatan dengan sumber air & & & & & & & & \\
\hline 2 & Akses ke badan air & & & & & & & & \\
\hline 3 & Jumlah akses ke badan air & $\sqrt{ }$ & & $\sqrt{ }$ & $\sqrt{ }$ & & $\sqrt{ }$ & $\sqrt{ }$ & Menambah akses ke badan air \\
\hline 4 & $\begin{array}{l}\text { Fungsi kawasan di luar } \\
\text { sempadan }\end{array}$ & & & & $\sqrt{ }$ & $\sqrt{ }$ & $\sqrt{ }$ & & Menambah fungsi lain pada kawasan tersebut \\
\hline 5 & Orientasi bangunan & & & & $\sqrt{ }$ & $\sqrt{ }$ & $\sqrt{ }$ & $\sqrt{ }$ & $\begin{array}{l}\text { Bangunan yang membelakangi badan air agar } \\
\text { membuat fasad yang menghadap ke situ (memiliki } 2 \\
\text { fasad depan) }\end{array}$ \\
\hline 6 & Jaringan transportasi & $\sqrt{ }$ & $\sqrt{ }$ & $\sqrt{ }$ & $\sqrt{ }$ & $\sqrt{ }$ & $\sqrt{ }$ & $\sqrt{ }$ & $\begin{array}{l}\text { Merencanakan akses ke badan air yang akan } \\
\text { ditambahkan agar menuju ke badan air (tidak } \\
\text { mengiris) yang berpengaruh pada orientasi bangunan } \\
\text { sekitar }\end{array}$ \\
\hline 7 & Tinggi bangunan & & & & $\sqrt{ }$ & & & & $\begin{array}{l}\text { Menetapkan maksimum ketinggian bangunan agar } \\
\text { tidak menghalangi pemandangan ke dalam situ pada } \\
\text { peraturan daerah }\end{array}$ \\
\hline 8 & Bangunan di sekitar sempadan & $\sqrt{ }$ & $\sqrt{ }$ & $\sqrt{ }$ & $\sqrt{ }$ & $\sqrt{ }$ & $\sqrt{ }$ & $\sqrt{ }$ & $\begin{array}{l}\text { - Menegaskan batas-batas sempadan } \\
\text { - Mengurangi dan merelokasi bangunan di dalam } \\
\text { sempadan }\end{array}$ \\
\hline 9 & Vegetasi penyangga riparian & & & $\sqrt{ }$ & $\sqrt{ }$ & $\sqrt{ }$ & $\sqrt{ }$ & $\sqrt{ }$ & Melakukan penanaman pohon pada daera riparian \\
\hline 10 & Kualitas perairan & & & & & & & $\sqrt{ }$ & $\begin{array}{l}\text { - Mengendalikan limbah domestik yang masuk } \\
\text { perairan } \\
\text { - Membuat kebijakan dan memberikan sanksi pada } \\
\text { pelaku pencemaran baik rumah tangga maupun } \\
\text { industri } \\
\text { - Mengawasi dan menjalankan kebijakan yang sudah } \\
\text { dibuat }\end{array}$ \\
\hline 11 & Tutupan tumbuhan air & & & & & & & & \\
\hline 12 & Bau dan warna & & & & & & & & \\
\hline 13 & Penyusutan badan air & $\sqrt{ }$ & & $\sqrt{ }$ & $\sqrt{ }$ & $\sqrt{ }$ & $\sqrt{ }$ & $\sqrt{ }$ & $\begin{array}{l}\text { - Pengerukan untuk material sedimentasi } \\
\text { - Penanaman vegetasi di daerah riparian } \\
\text { - Melengkapi inlet dengan water treatment }\end{array}$ \\
\hline
\end{tabular}

Keterangan: 1) Situ Cibeureum, 2) Situ Pemda/Baru, 3) Situ Cikaret, 4) Situ Kebantenan, 5) Situ Tonjong, 6) Situ Kemuning, 7) Situ Citatah/Ciriung

\section{SIMPULAN DAN SARAN}

Menilai lanskap situ dapat menggunakan lembar checklist sebagai pedoman dalam penilaian. Lembar checklist yang dibuat dalam penelitian ini menunjukkan bahwa kualitas perairan dan vegetasi penyangga riparian merupakan variabel terpenting dalam menentukan lanskap situ untuk dikembangkan sebagai waterfrront. Sehingga, dalam pengembangan waterfront perlu mempertimbangkan vegetasi penyangga riparian untuk menjaga kualitas perairan. Kedua variabel tersebut menjadi penting pada pengembangan waterfront untuk keberlanjutan ekosistem di sekitar situ baik ekosistem terestrial maupun ekosistem akuatik.

Hasil penilaian lanskap situ untuk pengembangan waterfront di Cibinong Raya, terdapat 3 situ dalam kondisi baik dan 4 situ dalam kondisi cukup baik. Situ yang memiliki kondisi lanskap baik adalah Situ Cibeureum (2.60), Situ Pemda/Baru (2.56), dan Situ Cikaret (2.34). Sedangkan situ yang memiliki kondisi lanskap cukup baik adalah Situ Kebantenan (2.28), Situ Tonjong (2.25), Situ Kemuning (2.21), dan Situ Citatah/Ciriung (1.90). Situ Cibeureum memiliki skor tertinggi karena terpenuhinya variabel kualitas perairan 
dan vegetasi penyangga riparian sesuai dengan kondisi yang diinginkan, dan mendapatkan skor tertinggi.

Situ-situ yang tidak dinilai kondisi lanskapnya menggunakan lembar chekclist pada penelitian ini (yang memiliki luas < $2.5 \mathrm{Ha}$ ), bukan berarti tidak layak untuk dikembangkan menjadi kawasan waterfront. Kesepuluh situ tersebut, dapat dikembangkan menjadi kawasan waterfront untuk skala yang lebih kecil. Beberapa situ yang kehilangan badan airnya (Situ Cipambuan Hilir, Situ Leuwi Nutug, dan Situ Nanggerang), dapat memulai dari pemulihan kondisi badan air situ berdasarkan ukuran SK yang ditetapkan dan untuk mengetahui kondisi lanskapnya dapat berpedoman pada lembar checklist yang dibuat.

\section{DAFTAR PUSTAKA}

Arikunto, S. 2010. Prosedur Penelitian: Suatu Pendekatan Praktik. Jakarta: Rineka Cipta.

Badan Pusat Statistik Kabupaten Bogor. 2015. Kabupaten Bogor dalam Angka 2015. Kabupaten Bogor: Badan Pusat Statistik Kabupaten Bogor.

Bupati Bogor. 2008. Peraturan Daerah Kabupaten Bogor Nomor 19 Tahun 2008 Rencana tentang Rencana Tata Ruang Wilayah Kabupaten Bogor Tahun 2005-2025. Kabupaten Bogor (ID): Pemerintah Kabupaten Bogor

Grant, J. 2004. Dialogue in Urban and Regional Planning Volume 1. dalam Stiftel, B., Watson, V. (ed). New York: Routledge.

Hallgren, K.A. 2012. Computing Inter-Rater Reliability for Observation Data: An Overview and Tutorial. Tutor Quant Methods Psychol. 8(1):23-34.

Irianto, E.W. dan Triweko, R.W. 2011. Eutrofikasi Waduk dan Danau: Permasalahan, Pemodelan, dan Upaya Pengendalian. Bandung: Pusat Penelitian dan Pengembangan Sumber Daya Air.

Kementerian Negara Lingkungan Hidup. 2008. Pedoman Pengelolaan Ekosistem Danau. Jakarta: Kementrian Negara Lingkungan Hidup.

Lagarense, B.E.S. 2013. Evaluating Waterfront Uses for Tourism and Recreation with Acceptance to Changes: The Case of Manado Waterfront Development. Journal of Business Review. 3(1):144-122.

Mardapi, D. 2008. Teknik Penyusunan Instrumen Tes dan Non Tes. Jogjakarta: Mitra Cendikia Press.

McHugh, M.L. 2012. Interrater Reliability: The Kappa Statistic. Biochemia Medica. 22(3):276-282.

New York State Departement of Environmental Conservation. 2009. Consolidated Assessment and Listing Methodology. http://www.dec.ny.gov/ (diakses 27 Okt 2016).

Soesanti S., Sastrawan, A., dan Rahman, A. 2006. Pola penataan zona, massa, dan ruang terbuka pada perumahan waterfront. Dimensi Teknik Arsitektur. 34(2):115-121.
Somba Henry Roy. 2014. Konsep waterfront city, solusi mengelola bantaran sungai. http://www. seputarsulut.com/ (diakses 04 Feb 2017).

Sugiarto, D.S. 2006. Metode Statistika: Untuk Bisnis dan Ekonomi. Jakarta: Gramedia Pustaka Utama.

Sugiyono. 2011. Metode Penelitian Kombinasi. Bandung: Alfabeta.

Tangkuman, D.J. dan Tondobala, L. 2011. Arsitektur Tepi Air (Waterfront Architecture). Jurnal Media Matrasain. 8(2):40-54.

The Council of the Town. 2015. Town of Huntsville Official Plan Section 8 Waterfront Policies. http://www.huntsville.ca/en/townHall/resourc es/DEV_OP_Section8_Jan2015.pdf (diakses 21 Nov 2016).

Truesdale A. 2008. Maine Shoreland Zoning (A Handbook for Shoreland Owners). Maine Departement of Environmental Protection (DEP): DEPLW0674-D08.

U.S. Departement of Agriculture. 2003. Where the Land and Water Meet: A Guide for Protection and Restoration of Riparian Areas. New York: Pennsylvania DEP.

Yassin, A.B., Bond, S. dan McDonagh, J. 2011. Developing Guidelines For Riverfront Developments for Malaysia. Pacific Rim Property Research Journal. 17(4):511-530. 